University of Nebraska - Lincoln

DigitalCommons@University of Nebraska - Lincoln

Faculty Publications: Department of Entomology

August 1983

\title{
Factors Influencing Adult Emergence from Diapausing Sorghum Midge, Contarinia sorghicola (Diptera: Cecidomyiidae
}

Frederick P. Baxendale

University of Nebraska-Lincoln, fbaxendale1@unl.edu

G. L. Teetes

Texas A \& M University

Follow this and additional works at: https://digitalcommons.unl.edu/entomologyfacpub

Part of the Entomology Commons

Baxendale, Frederick P. and Teetes, G. L., "Factors Influencing Adult Emergence from Diapausing Sorghum Midge, Contarinia sorghicola (Diptera: Cecidomyiidae" (1983). Faculty Publications: Department of Entomology. 139.

https://digitalcommons.unl.edu/entomologyfacpub/139

This Article is brought to you for free and open access by the Entomology, Department of at DigitalCommons@University of Nebraska - Lincoln. It has been accepted for inclusion in Faculty Publications: Department of Entomology by an authorized administrator of DigitalCommons@University of Nebraska - Lincoln. 


\title{
Factors Influencing Adult Emergence from Diapausing Sorghum Midge, Contarinia sorghicola (Diptera: Cecidomyiidae) ${ }^{1}$
}

\author{
F. P. BAXENDALE AND G. L. TEETES \\ Department of Entomology, Texas A\&M University, College Station, Texas 77843
}

\begin{abstract}
Environ. Entomol. 12: 1064-1067 (1983)
ABSTRACT Sorghum midge, Contarinia sorghicola (Coquillett) diapause was terminated in the laboratory, and factors affecting adult emergence from diapausing larvae were investigated. Temperatures in the range from 20 to $30^{\circ} \mathrm{C}$ were optimum for diapause termination and adult emergence. Diapausing larvae exposed to moist conditions at $30^{\circ} \mathrm{C}$ began to emerge as adults after 12 days of incubation. Based on adult emergence rates per day, an emergence threshold temperature was estimated to be $14.8^{\circ} \mathrm{C}$. Exposure to 12 to 13 days of continuous moisture at $30^{\circ} \mathrm{C}$ was essential for diapause termination and adult emergence. Moisture acted to initiate diapause termination, but diapausing larvae were unable to accumulate shorter periods of moisture toward the 12- to 13-day requirement. Photoperiod had no significant effect on the termination of larval diapause.
\end{abstract}

The sorghum midge, Contarinia sorghicola (Coquillett) (Diptera: Cecidomyiidae), is a key insect pest of sorghum (Young and Teetes 1977). Eggs are deposited within flowering spikelets, and the maturing larvae feed on the ovary, which prevents seed development. The life cycle of the sorghum midge is completed in 14 to 18 days, which permits from 9 to 11 overlapping generations per season (Harding 1965).

Depending on environmental conditions, a variable proportion of sorghum midge larvae construct silken cocoons and initiate diapause within the spikelets of the host plant (Baxendale 1980). Normally, these spikelets fall to the ground and become covered with litter or are disked into the soil along with plant residues.

Control of the sorghum midge is achieved primarily through early uniform regional planting of sorghum to avoid high midge densities during the susceptible flowering period. Particularly important to this strategy is a sound understanding of the environmental factors which influence diapause termination, predictive data on the spring emergence of overwintered sorghum midges and early-season population dynamics.

Because of the critical nature of this information, various workers have attempted to elucidate the factors influencing diapause termination. Harding (1965) was unable to terminate diapause in the laboratory except when diapausing larvae had remained in the field throughout the winter. Passlow (1965) carried out a series of diapause termination experiments in which he exposed diapausing larvae to various combinations of temperature and relative humidity (RH). He reported that midges terminate diapause and emerge as adults when subjected to temperatures from 16 to $32^{\circ} \mathrm{C}$ with RH above $94 \%$. Under optimum conditions of $28^{\circ} \mathrm{C}$ with $98 \% \mathrm{RH}$, adults began to emerge after 13 days of incubation. Unfortunately, in reporting these data, Passlow failed to provide either the actual number or distribution of emerged adults. Without this information, the usefulness of the data for determining emergence threshold temperatures or for predicting field emergence

'Approved as TA 16899 by Director, Tex. Agric. Exp. Stn. Received for publication 17 August 1982; accepted 4 January 1983. is limited. Further, Passlow conducted no experiments to determine the influence of moisture independent of temperature, or of photoperiod on diapause termination.

In the present study, laboratory investigations were carried out to determine the specific effects of selected constant temperatures, moisture treatments, and photoperiods on the magnitude and distribution of sorghum midges terminating diapause and emerging as adults.

\section{Materials and Methods}

Sorghum spikelets containing diapausing sorghum midge larvae were collected from the field during early October and returned to laboratory before the onset of cold weather. These spikelets were stored at room temperature (ca. $22^{\circ} \mathrm{C}$ and $50 \% \mathrm{RH}$ ) for ca. 6 to 8 months until termination experiments were initiated. At that time, diapausing larvae within sorghum spikelets were exposed to a range of constant temperatures, moisture treatments, and photoperiods. Studies were conducted in environmental chambers fitted with fluorescent lamps for illumination. In each experiment, sorghum spikelets from a minimum of 100 midge-infested sorghum panicles were randomly mixed. A $6-\mathrm{g}$ amount of mixture was placed between two layers of perlite within 473-ml plastic food containers sealed with clear plastic covers. Containers were assumed to contain an equal number of diapausing larvae because of the randomization process. Moistened treatments were obtained by adding $75 \mathrm{ml}$ of distilled water to each container to saturate the perlite medium. This exposed diapausing larvae to free water (100\% RH) conditions.

The criterion for diapause termination was emergence of adult midges. Emerged adults were removed from containers and counted at 1- or 2-day intervals. After emergence of the last adult midge, the number of days to first, mean, and last emergence was determined.

\section{Effects of Temperature}

The influence of temperature on diapause termination and subsequent adult emergence was tested by using environmental chambers maintained at $10,15,20,25$, 30,35 , or $40^{\circ} \mathrm{C}$, with 14 -h photophase. Spikelets in a total of 35 containers were saturated with distilled water 
and were placed at each temperature. Adult emergence was recorded daily for a period of 100 days.

\section{Effects of Moisture}

Two experiments were conducted to determine the response of diapausing sorghum midge larvae to freewater $(100 \% \mathrm{RH})$ conditions. In the first, diapause termination and subsequent adult emergence were evaluated in the presence and absence of moisture. Twenty test containers were prepared, using dry, midge-infested sorghum spikelets. Five of these containers were saturated with distilled water, and all 20 were placed in an environmental chamber maintained at $30^{\circ} \mathrm{C}$, with a 14 $h$ photophase. On day 10 and again on day 20 of incubation, five additional test containers were moistened. The five remaining containers were never moistened during the incubation period. Emerged adults were removed and counted daily.

In the second moisture experiment, the effects of the duration of exposure to moisture on diapausing larvae were examined. Eighty test containers were saturated with distilled water and were placed in an environmental chamber maintained at $30^{\circ} \mathrm{C}$, with a 14 -h photophase. After $24 \mathrm{~h}$, the spikelets in five of the 80 containers were removed and rapidly dried under a fume hood. The spikelets were then placed between two layers of clean, dry perlite and were returned to the environmental chamber. Each day for the next 15 days, spikelets from five additional containers were dried and returned to the chamber by a similar procedure. In this manner, 16 treatments of diapausing larvae having received from 1 to 16 days of exposure to moisture had been generated. On day 30 of incubation, all 80 containers were saturated with distilled water. Adult emergence was recorded daily throughout the experiment.

\section{Effects of Photoperiod}

The influence of photoperiod on diapause termination was examined, using environmental chambers maintained at $30^{\circ} \mathrm{C}$ with a 5-, 10-, 14-, 20-, or 24-h photophase. Midge-infested spikelets in five test containers were saturated with distilled water and were placed at each photoperiod regime. Emerged adults were recorded at 2-day intervals.

\section{Results and Discussion}

\section{Effects of Temperature}

Temperatures in the range of 20 to $30^{\circ} \mathrm{C}$ were optimum for diapausing larvae to complete development and emerged as adults (Table 1). Although the greatest number of adult midges emerged at $25^{\circ} \mathrm{C}$, larvae maintained at $30^{\circ} \mathrm{C}$ had the shortest developmental times and began to emerge as adults after 12 days of incubation. No adult midges emerged at either 10 or $40^{\circ} \mathrm{C}$ during the 100 day incubation period.

A linear regression analysis, based on adult emergence rates per day, was used to estimate an emergence threshold temperature of $14.8^{\circ} \mathrm{C}$ (Fig. 1). Since no adult midges emerged at $10^{\circ} \mathrm{C}$ and only two emerged at $15^{\circ} \mathrm{C}$, the threshold estimate seemed reasonable. This emergence threshold temperature can be used in a thermal accretion model to estimate the spring emergence of sorghum midges overwintering in the field.

\section{Effects of Moisture}

Results of the first moisture experiment indicated that moisture initiated diapause termination in diapausing sorghum midge larvae. When diapausing larvae were incubated in the absence of moisture, no adult midges emerged (Table 2). However, when diapausing larvae were incubated and then moistened after 0,10 , or 20 days, the number of days to first, mean, and last emergence increased in a stepwise manner, with emergence taking ca. 10 days longer in each subsequent treatment. The number and distribution of emerged adults, however, remained similar in all moistened treatments.

Results of the second moisture experiment suggested that the presence of moisture is necessary throughout both the diapause termination and subsequent adult emergence processes (Table 3 ). Sorghum midge larvae initially exposed to 1 to 12 days of moisture at $30^{\circ} \mathrm{C}$ before being dried did not complete development and emerge as adults in the 30 days before the re-addition of water. However, larvae exposed to 13 to 16 days of moisture before being dried completed development normally and emerged as adults after 13 to 14 days. After the drying process, however, there was no further

Table 1. Effects of exposure to constant temperatures on diapause termination and subsequent emergence of adult sorghum midges ${ }^{\circ}$

\begin{tabular}{lccccc}
\hline \hline Temp $\left({ }^{\circ} \mathrm{C}\right)$ & $\begin{array}{c}\text { No. of emerged } \\
\text { adults }\end{array}$ & $\begin{array}{c}\text { First emergence } \\
\text { (days) }\end{array}$ & $\begin{array}{c}\overrightarrow{\mathrm{x}} \text { Emergence } \\
\text { (days) }\end{array}$ & $\begin{array}{c}\text { Emergence period } \\
\text { (days) })^{h}\end{array}$ & Emergence rate/dayc \\
\hline
\end{tabular}

$\begin{array}{rrrccc}10 & 0 & - & - & - & -\overline{0} \\ 15 & 2 & 48 & 66.50 & 85 & 1.62 \\ 20 & 115 & 26 & 37.16 & 54 & 4.52 \\ 25 & 244 & 13 & 19.81 & 25 & 5.16 \\ 30 & 129 & 12 & 17.05 & 48 & 0.15 \\ 35 & 7 & 22 & -33.57 & - & -\end{array}$


Table 2. Emergence of sorghum midge adults after the addition of water at 10-day intervals to incubated diapausing larvae

\begin{tabular}{ccccc}
\hline $\begin{array}{c}\text { Days of incubation } \\
\text { before addition } \\
\text { of water }\end{array}$ & $\begin{array}{c}\overline{\mathrm{x}} \text { No. of } \\
\text { emerged adults }\end{array}$ & $\begin{array}{c}\text { First emergence } \\
(\overline{\mathrm{x}} \text { days })^{b}\end{array}$ & $\begin{array}{c}\overline{\mathrm{x}} \text { emergence } \\
\text { (days) }^{b}\end{array}$ & $\begin{array}{c}\text { Last emergenc } \\
(\overline{\mathrm{x}} \text { days })^{b}\end{array}$ \\
\hline 0 & $20.4 \mathrm{a}$ & $12.6 \mathrm{c}$ & $18.3 \mathrm{c}$ & $28.4 \mathrm{c}$ \\
10 & $14.0 \mathrm{a}$ & $25.0 \mathrm{~b}$ & $27.9 \mathrm{~b}$ & $38.8 \mathrm{~b}$ \\
20 & $20.2 \mathrm{a}$ & $33.4 \mathrm{a}$ & $39.1 \mathrm{a}$ & $46.0 \mathrm{a}$ \\
No water added & 0 & - & - & - \\
\hline
\end{tabular}

${ }^{\circ}$ Temperature $=30^{\circ} \mathrm{C}$, photoperiod $=\mathrm{LD} 14: 10$.

${ }^{b}$ Means in the same column followed by the same letter are not significantly different at the $5 \%$ level, by Duncan's multiple range test.

adult emergence until after the re-addition of water on day 30 .

After the re-addition of water to all treatments on day 30 of the experiment, adult midges began to emerge only after an additional 9 to 15 days of incubation. Interestingly, although there were no significant differences in the number of days to mean emergence among treatments, most mean times were shorter than would normally be expected at $30^{\circ} \mathrm{C}$. There was no evidence, however, that periods of exposure to moist conditions could be accumulated. If exposure to moisture was cumulative, those larvae receiving longer exposures before drying would have emerged as adults, after the re-addition of water, before larvae receiving shorter exposures to moisture. This did not happen.

As the number of days diapausing larvae were exposed to moisture before being dried increased, the number of adults that emerged after the re-addition of water decreased. This trend was particularly evident when diapausing larvae were initially exposed to more than 9 days of moisture. Apparently, the further diapause termination had progressed, the greater the difficulty midges

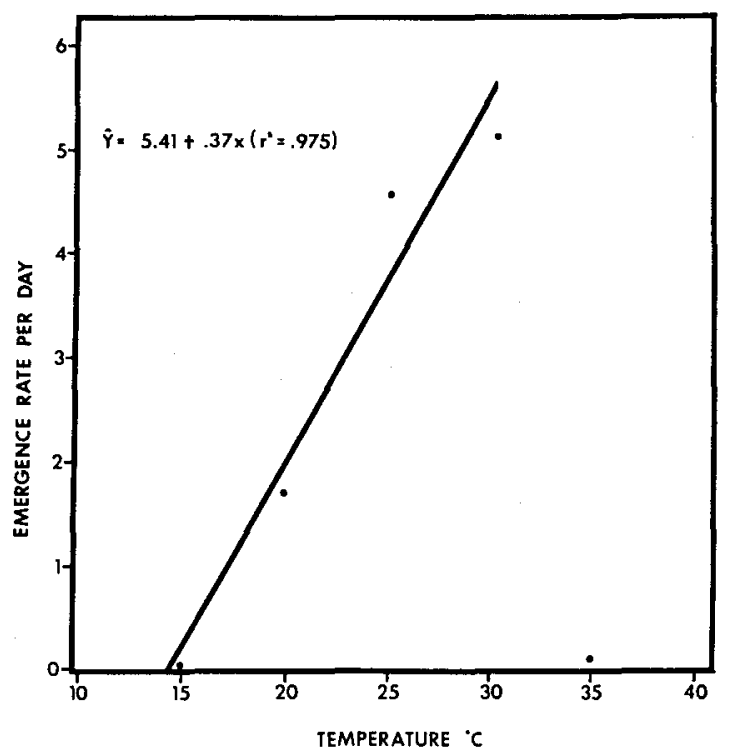

FIG. 1. Regression for calculating the emergence threshold temperature for the sorghum midge. had in reversing the process. However, those individual that survived the dry period began to emerge more o less normally 9 to 15 days after the re-addition of water

\section{Effects of Photoperiod}

Diapausing larvae exposed to identical conditions o temperature $\left(30^{\circ} \mathrm{C}\right)$ and moisture $(100 \% \mathrm{RH})$ but to dif ferent photoperiods, showed no significant difference in the number of days to first, mean, or last adult emer gence. Apparently, diapause termination was not a pho toperiod-initiated response.

\section{Acknowledgment}

This research was supported in part by grant AID/DSAN XII/G-0149 from the Agency for International Development Washington, D.C. Project No. H-6216.

\section{REFERENCES CITED}

Baxendale, F. P. 1980. Diapause termination, overwintering emergence and the seasonal abundance of the sorghum midge Contarinia sorghicola (Coquillett) and its parasites. M.S thesis, Texas A\&M University, College Station. $177 \mathrm{pp}$.

Table 3. Emergence of sorghum midge adults before and afte the re-addition of water to incubated diapausing larvae exposet initially to increasing days of moist conditions ${ }^{a}$

\begin{tabular}{|c|c|c|}
\hline \multirow{2}{*}{$\begin{array}{l}\text { Initial exposure } \\
\text { to moisture } \\
\text { (days) }\end{array}$} & $\overline{\mathrm{x}}$ No. of emerged adults: & \multirow{2}{*}{$\begin{array}{l}\bar{x} \text { Adult emergenci } \\
\text { after re-addition } \\
\text { of water (days) }{ }^{b}\end{array}$} \\
\hline & $\begin{array}{l}\text { Before re-addition After re-addition } \\
\text { of water of water }\end{array}$ & \\
\hline
\end{tabular}

\begin{tabular}{rlcc}
\hline 1 & & & \\
2 & 0 & $20.8 \mathrm{a}$ & $16.6 \mathrm{a}$ \\
3 & 0 & $18.2 \mathrm{a}$ & $16.4 \mathrm{a}$ \\
4 & 0 & $15.6 \mathrm{abc}$ & $14.8 \mathrm{a}$ \\
5 & 0 & $17.0 \mathrm{ab}$ & $14.3 \mathrm{a}$ \\
6 & 0 & $9.4 \mathrm{cde}$ & $13.5 \mathrm{a}$ \\
7 & 0 & $6.4 \mathrm{def}$ & $14.3 \mathrm{a}$ \\
8 & 0 & $9.2 \mathrm{cde}$ & $13.9 \mathrm{a}$ \\
9 & 0 & $6.8 \mathrm{def}$ & $14.0 \mathrm{a}$ \\
10 & 0 & $11.4 \mathrm{bcd}$ & $13.1 \mathrm{a}$ \\
11 & 0 & $3.2 \mathrm{ef}$ & $14.3 \mathrm{a}$ \\
12 & 0 & $3.4 \mathrm{ef}$ & $12.4 \mathrm{a}$ \\
13 & 0 & $2.2 \mathrm{ef}$ & $15.5 \mathrm{a}$ \\
14 & 0.2 & $1.8 \mathrm{f}$ & $16.1 \mathrm{a}$ \\
15 & 0.4 & $2.4 \mathrm{ef}$ & $13.1 \mathrm{a}$ \\
16 & 2.4 & $0 \mathrm{f}$ & - \\
& 1.6 & $0.4 \mathrm{f}$ & $15.0 \mathrm{a}$ \\
\hline
\end{tabular}

"Temperature $=30^{\circ} \mathrm{C}$, photoperiod $=$ LD 14:10.

${ }^{\text {h}}$ Means in the same column followed by the same letter are not significantly different at the $5 \%$ level, by Duncan's multiple range test. 
Harding, J. 1965. Ecological and biological factors conceming the sorghum midge in 1964. Tex. Agric. Exp. Stn. MP773. $10 \mathrm{pp}$.

Passlow, T. 1965. Bionomics of sorghum midge (Contarinia sorghicola (Coq.) in Queensland, with particular reference to diapause. Queensl. J. Agric. Anim. Sci. 22: 150-167.

Young, W. R., and G. L. Teetes. 1977. Sorghum entomology. Annu. Rev. Entomol. 22: 193-218. 